\title{
Chapter 3 \\ Migration and Immigrants in Europe: A Historical and Demographic Perspective
}

\author{
Christof Van Mol and Helga de Valk
}

\section{Introduction}

This chapter outlines the general developments of migration within and towards Europe as well as patterns of settlement of migrants since the 1950s. We take as our starting point the bilateral labour migration agreements signed by several European countries in the 1950s and 1960s. Three main periods can be distinguished from this point onwards. The first, up to the oil crisis in 1973-1974, was characterized by steady economic growth and development and deployment of guest worker schemes, (return) migration from former colonies to motherlands, and refugee migration, mainly dominated by movements from East to West. The second period started with the oil crisis and ended with the fall of the Iron Curtain in the late 1980s. During this time North-Western European governments increasingly restricted migration, and migrants' main route of entrance became family reunification and family formation. Furthermore, asylum applications increased. By the end of this period, migration flows had started to divert towards former emigration countries in Southern Europe. The third period is from the fall of the Iron Curtain until today, with increasing European Union (EU) influence and control of migration from third countries into the EU and encouragement of intra-European mobility.

The historical overview presented here stems from a comprehensive literature study, complemented by an analysis of available statistical data for trends in the last

\footnotetext{
C. Van Mol ( $\triangle)$

Netherlands Interdisciplinary Demographic Institute/ KNAW/UG,

The Hague, The Netherlands

e-mail: mol@nidi.nl

H. de Valk

Netherlands Interdisciplinary Demographic Institute/ KNAW/UG,

The Hague, The Netherlands
}

Free University, Brussels, Belgium 
decade. It should be noted, however, that statistical data on migration and mobility in Europe is mostly incomplete, as they are based mainly on reports and registrations of the individuals concerned. Besides, data on immigration and emigration are not always fully available and are not consistently measured across countries and time (see, e.g., EMN 2013). This means that the quality of migration data is often limited (Abel 2010; Kupiszewska and Nowok 2008; Nowok et al. 2006; Poulain et al. 2006). Several initiatives and projects have been launched to overcome these problems and promote comparable definitions, statistics, and estimations of missing data (Raymer et al. 2011). Most of the EU's current 28 member countries produce annual statistics on immigration and emigration. However, the information and level of detail is not yet comparable across countries (for an overview of databanks and limitations, see Raymer et al. 2011). The final section of this chapter presents figures on migration and migrants relying mainly on data from three research projects which aimed to create and improve harmonized and consistent migration data (Abel and Sander 2014; Raymer et al. 2011, see www.nidi.nl for more information on the MIMOSA and IMEM projects). The conclusion summarizes the main patterns and discusses some implications of our findings.

\section{Three Periods of Migration in Europe}

\section{From the 1950s to 1974: Guest Worker Schemes and Decolonization}

In the period after the Second World War, North-Western Europe was economically booming. Industrial production, for example, increased by $30 \%$ between 1953 and 1958 (Dietz and Kaczmarczyk 2008). Native workers in this region became increasingly educated, and growing possibilities for social mobility enabled many of them to move up to white-collar work (Boyle et al. 1998). Local workers could not fill the vacancies, as labour reservoirs were limited. Furthermore, the local native population was no longer willing to take up unhealthy and poorly paid jobs in agriculture, cleaning, construction, and mining. As a result, North-Western European governments started to recruit labour in peripheral countries. The main destination countries were Belgium, France, Germany, Luxembourg, the Netherlands, Sweden, and Switzerland. The recruited foreign workers were expected to return home after completing a stint of labour. They therefore tended to be granted few rights and little or no access to welfare support (Boyle et al. 1998). At the end of this period, most migrants in North-Western Europe originated from Algeria, Greece, Italy, Morocco, Portugal, Spain, Tunisia, Turkey, and Yugoslavia.

Initially, geographical proximity played an important role in the development of specific migration flows. For example, Sweden recruited labour from Finland, the UK from Ireland, and Switzerland from Italy. A migration system emerged whereby peripheral-especially Southern European-countries supplied workers to North-Western European countries. Migration flows were strongly guided by differences in economic development between regions characterized by pre-industrial 
agrarian economies and those with highly industrialized economies (Bade 2003; Barou 2006), both internationally and nationally (e.g., with unskilled workers moving from Southern Italy towards the industrial centres in Northern Italy). Within the origin countries, most migrant workers were from poor agricultural regions where there was insufficient work, such as Northern Portugal, Western Spain, Southern Italy, and Northern Greece (Bade 2003). However, European governments gradually enlarged their zones of recruitment to countries outside Europe. One of the main reasons was the Cold War division of Europe which severely restricted East-West labour mobility. In West Germany, for example, there was a significant inflow of workers from Greece, Italy, and Spain, as well as from East Germany. The construction of the Berlin Wall in 1961, however, put a stop to the latter. As a result, West Germany reoriented its recruitment towards elsewhere. Bilateral agreements were signed with Turkey (1961), Morocco (1963), Portugal (1964), Tunisia (1965), and Yugoslavia (1968). Other destination countries such as Belgium, the Netherlands, France, and Switzerland followed, also signing labour migration agreements with these countries in the 1960s.

In this period, international migration was generally viewed positively because of its economic benefits (Bonifazi 2008), from the perspective of both the sending and the receiving countries. In the Mediterranean region, for example, emigration helped to alleviate pressures on the labour market, as the region was characterized by significant demographic pressure, low productivity and incomes, and high unemployment (Page Moch 2003; Vilar 2001). A comparison of annual gross national product per capita in the 1960s illustrates this with US $\$ 353$ for Turkey, $\$ 822$ for Spain, and \$1272 for Italy; \$1977 for the UK and \$2324 for France (Page Moch 2003, 180). Furthermore, migrants' remittances were expected to benefit the national economy. In Turkey, for example, the monetary returns of migrants became a vital element of the economy: the country even experienced economic destabilization when labour migration to Germany ended in 1974 (Barou 2006). However, reasons for origin countries to support emigration went beyond the economic. The Italian government, for example, considered the labour migration programmes of North-Western European countries as a way to 'get rid of the unemployed and to deprive the socialist and communist parties of potential voters' (Hoerder 2002, 520).

Estimates of the numbers of individuals that left Italy, Spain, Greece, and Portugal between 1950 and 1970 vary from 7 to 10 million (Okólski 2012). As can be seen from Table 3.1, in 1950 immigrant populations were most numerous in France, the UK, Germany, and Belgium.

Twenty years later, at the beginning of the 1970s, these numbers had increased substantially in both absolute and relative terms (Table 3.1). One in seven manual labourers in the UK and one in four industrial workers in Belgium, France, and Switzerland were of foreign origin in the mid-1970s (Page Moch 2003, not in table). Eighty per cent of the total foreign stock in 1975 was concentrated in four countries, namely France, Germany, Switzerland, and the UK (Bonifazi 2008).

At the same time, the process of decolonization gave rise to considerable migration flows towards Europe's (former) colonial powers. A significant number of people from the colonies came to Belgium, France, the Netherlands, the UK, and in the 1970s, Portugal. Many of these (return) migrants were juridically considered 
Table 3.1 Minority populations in the main Western-European countries of immigration, 19501975 (thousands and last column \% of total population)

\begin{tabular}{l|r|r|r|r|l}
\hline Country & & & & & $\begin{array}{l}\text { As per cent of total } \\
\text { population 1975 }\end{array}$ \\
\hline Belgium & 1950 & 1960 & 1970 & 1975 & 835 \\
\hline France & 354 & 444 & 716 & 8.5 \\
\hline West Germany & 2128 & 2663 & 3339 & 4196 & 7.9 \\
\hline Netherlands & 548 & 686 & 2977 & 4090 & 6.6 \\
\hline Sweden & 77 & 101 & 236 & 370 & 2.6 \\
\hline Switzerland & 124 & 191 & 411 & 410 & 5.0 \\
\hline United Kingdom & 279 & 585 & 983 & 1012 & 16.0 \\
\hline
\end{tabular}

Source: Castles et al. $(2014,108)$. See Castles et al. (1984, 87-88) for detailed sources

Notes: Figures for all countries except the UK are for foreign residents. They exclude naturalized persons and immigrants from the Dutch and French colonies. UK data are census figures for 1951, 1961, and 1971 and estimates for 1975. The 1951 and 1961 data are for overseas-born persons and exclude children born to immigrants in the UK. The 1971 and 1975 figures include children born in the UK, with both parents born abroad

citizens; estimates suggest that between 1940 and 1975 the number of people of European origin returning from the colonies was around 7 million (Bade 2003). The main (return) migration flows were from Kenya, India, and Malaysia to the UK, from Northern Africa to France and Italy, from Congo to Belgium (although in smaller numbers), and from Indonesia to the Netherlands (Bade 2003). Some of these migrants, as for example from the new Commonwealth, came for economic reasons (Page Moch 2003). Others, such as the Algerian harkis (auxiliaries in the French colonial army) in France, Asian Ugandans in Britain, and a substantial share of Surinamese in the Netherlands, arrived during or after independence (ibid.). In the 1970s, Portugal received a significant number of citizens "returning" from its former colonies, fleeing from violent combats in the struggle for independence. Although European migrants returning from the colonies were often quickly able to insert themselves into the social fabric of the mother country, this was less the case for those of non-European origin who were economically and socially deprived and also often discriminated (Bade 2003).

Lastly, the Iron Curtain severely limited East-West mobility. Nevertheless, it did not bring East-West migration to a complete halt (Fassmann and Münz 1994). Straddling our period demarcations we discuss these migrations patterns here, as they started in this period. Between 1950 and 1990, 12 million people migrated from East to West (Fassmann and Münz 1992), many of them to Germany. Between 1950 and 2004, for example, 4.45 million Aussiedler - ethnic Germans from Central and Eastern Europe-returned to Germany (Dietz 2006). Until 1988, most of these Aussiedler migrated from Poland (Dietz 2006; Münz and Ulrich 1998). Nevertheless, the largest share of these Aussiedler (63\%) arrived after 1989 (Dietz 2006). The vast majority who came after the fall of the Iron Curtain originated from the former Soviet Union (Dietz 2006; Münz and Ulrich 1998). Occasionally, however, there were larger inflows of Eastern Europeans, following political crises such as from Hungary (1956-1957), Czechoslovakia (1968-1969), and Poland (1980-1981) 
(Castles et al. 2014; Fassmann and Münz 1992, 1994). In line with the logic of the Cold War, whatever the motives of those who moved to the West, they were considered to be political refugees (Fassmann and Münz 1994).

\section{From 1974 to the End of the 1980s: The Oil Crisis and Migration Control}

The oil crisis of 1973-1974 had considerable impact on the economic landscape of Europe. The crisis gave impetus to economic restructuring, sharply reducing the need for labour (Boyle, Halfacree \& Robinson 1998). During this period, belief in unbridled economic growth diminished. Switzerland and Sweden were the first countries to invoke a migration stop, respectively, in 1970 and 1972. Others followed: Germany in 1973 and the Benelux and France in 1974. Policies aiming to control and reduce migration, however, transformed rather than stopped migration. The number of foreign residents kept rising, due to a change in European migration systems from circular to chain migration and the related natural growth of migrant populations. Migrants from non-European countries who had come under labour recruitment schemes increasingly settled permanently, as returning to their home country for long periods now entailed a significant risk of losing their residence permit. Many migrants started to bring their families to Europe. Although governments initially tried to limit family migration, this met little success (Castles et al. 2014; Hansen 2003). After all, family reunification of migrant workers was considered a fundamental right, anchored in article 19 of the European Social Charter of 1961.

The composition of the residing migrant population also changed during this period. Whereas in the first period, European migrants were most numerous, the share of non-European migrant populations significantly grew during the second period. In Sweden, for example, $40 \%$ of the foreign born were non-European by 1999, compared to only $7.6 \%$ in 1970 (Goldscheider et al. 2008). This reflected the continuing immigration and natural growth of these populations. But it was also the result of a larger extent of return migration among Southern European populations, given the increased quality of life and employment opportunities in Southern Europe (Barou 2006). In countries on the other side of the Mediterranean, population pressure continued to be substantial, due to high fertility and unemployment rates. During this period, the number of Greek, Italian, Portuguese, Spanish, and Yugoslavian foreigners in Europe diminished (except in Switzerland, where the number of Portuguese and Yugoslavians grew), and a significant increase was observed in the number of Turks and North Africans across Europe (Bade 2003).

After the migration stop, countries increasingly controlled entries of foreigners, and migration became an important topic in national political and public debates (Bonifazi 2008; see also Doomernik \& Bruquetas in this volume). Increasing unemployment levels due to the economic recession fuelled hostility, racism, and xenophobia towards certain "visible" groups of resident migrants. In several European 
countries, violent anti-foreigners incidents occurred. In France, for example, Le Pen's Front National acquired considerable political support for its simple message that '2 million unemployed $=2$ million immigrants too many' (Boyle et al. 1998, 27). During this period, however, awareness also grew that immigrant populations were here to stay. As a result, the need for adequate integration policies became apparent, and such policies slowly started to develop (see Doomernik and Bruquetas in this volume).

In this same phase, numbers of asylum applications started to rise in Europe (especially in the 1980s and after the fall of the Berlin Wall; Hansen 2003). Between the early 1970s and the end of the twentieth century the number of asylum applications in the EU, at that time 15 member states, increased from 15,000 to 300,000 annually (Hatton 2004). Germany was the largest recipient of asylum applications in Europe in all periods (Table 3.2). From the 1980s onwards, significant increases were also observed in Belgium, the Netherlands, and the UK. The different attractiveness of particular European countries over time is related to historical events that have induced new refugee flows. The dramatic increase in asylum applications from within Europe in the early 1990s, for example, accompanied the disintegration of the Soviet Union and the Yugoslavian wars (Hatton 2004, see also further on in this chapter).

The restrictions on the entrance of foreigners into North-Western Europe also had another effect. From the mid-1980s onwards, migration flows increasingly diverted towards Southern Europe, especially gaining momentum in the 1990s.

Table 3.2 Asylum applications to the EU-15 by destination country, 1970-1999 (thousands)

\begin{tabular}{l|l|l|r|r|r|r}
\hline & \multicolumn{7}{l}{ Years } & \multicolumn{1}{l}{} \\
\cline { 2 - 7 } & $1970-74$ & $1975-79$ & $1980-84$ & $1985-89$ & $1990-94$ & $1995-99$ \\
\hline Total EU applications & 64.5 & 213.7 & 540.2 & 1012.3 & 2419.8 & 1613.5 \\
\hline Austria & 8.7 & 14.7 & 63.2 & 64.4 & 76.1 & 53.5 \\
\hline Belgium & 1.7 & 6.6 & 14.5 & 32.1 & 87.0 & 93.4 \\
\hline Denmark & 3.7 & 1.3 & 5.6 & 42.1 & 76.4 & 36.0 \\
\hline Finland & - & - & 0.1 & 0.3 & 11.4 & 6.9 \\
\hline France & \multicolumn{1}{|c}{5.1} & 40.5 & 106.3 & 178.7 & 184.5 & 112.2 \\
\hline Germany & 34.3 & 121.8 & 249.6 & 455.3 & 1374.7 & 749.6 \\
\hline Greece & & 9.2 & 6.4 & 24.0 & 12.8 & 11.8 \\
\hline Ireland & - & - & - & - & 0.5 & 21.2 \\
\hline Italy & 11.0 & 9.2 & 16.5 & 26.3 & 40.8 & 48.8 \\
\hline Luxembourg & - & - & - & - & 0.1 & 5.7 \\
\hline Netherlands & - & 5.3 & 8.8 & 46.4 & 151.1 & 170.4 \\
\hline Portugal & 0 & 1.7 & 4.3 & 1.3 & 3.9 & 1.7 \\
\hline Spain & - & - & 5.4 & 15.7 & 53.1 & 30.4 \\
\hline Sweden & - & - & 41.9 & 97.1 & 197.0 & 48.5 \\
\hline United Kingdom & - & 3.4 & 17.5 & 28.5 & 150.8 & 223.3 \\
\hline
\end{tabular}

Source: Hatton $(2004,10)$. The numbers in Hatton (2004) are based on UNCHR (2001, Tables I.2, II.2, III.2, IV.2, VI.4, and VI.5) 
Greece, Italy, Portugal, and Spain had long been emigration countries. As a result, they did not dispose of well-developed immigration legislation and entrance control systems. Furthermore, these countries were experiencing economic growth and falling birth rates, resulting in labour shortages (Castles et al. 2014). The jobs available were often irregular ones, characterized by unfavourable labour conditions and low pay, making them unattractive to the local population. Southern Europe thus became an attractive destination for non-European migrants, especially those from North Africa, Latin America, Asia, and - after the fall of the Iron Curtain-Eastern Europe (Castles et al. 2014).

Besides migration flows from non-European countries, the favourable economic conditions in Southern Europe also resulted in return migration among those who had moved to Northern Europe. Spain, for example, registered the return of 451,000 citizens during this period, of which $94 \%$ had resided in another EU country (Barou 2006). Portugal, in contrast, experienced return migration from its former colonies, where fierce and violent struggles for independence were under way. Greece was the last country to transition from an emigration into an immigration country. Until 1973, some 1 million Greeks were working abroad (Bade 2003). Half of them returned in the period after the oil crisis (ibid.).

\section{From the 1990s to 2012: Recent Trends in Migration towards and Within Europe}

Patterns of migration from, towards, and within Europe underwent significant changes and further diversification starting in 1990. The collapse of the Iron Curtain and the opening of the borders of Eastern Europe induced new migration flows across Europe. The end of the Cold War, as well as the wars in the former Yugoslavia led to new flows of asylum seekers to Western Europe. Between 1989 and 1992, for example, asylum applications increased from 320,000 to 695,000 , to decline to 455,000 by the end of the decade (Hansen 2003) and increase again to 471,000 in 2001 (Castles et al. 2014). The top-five countries of origin during this period were the Federal Republic of Yugoslavia $(836,000)$, Romania $(400,000)$, Turkey $(356,000)$, Iraq $(211,000)$, and Afghanistan $(155,000)$ (ibid.). In the first decade of the twenty-first century, new asylum applications followed the conjuncture of admission restrictions and numbers of violent conflicts (ibid.). Between 2002 and 2006, asylum applications in the EU-15 decreased from 393,000 to 180,000 (ibid.). From 2006 onwards, however, asylum applications rose due to the conflicts in Afghanistan, Iraq, and more recently, the Arab Spring. By 2010, the EU-25 plus Norway and Switzerland had received 254,180 applications, and humanitarian migration accounted for $6 \%$ of newcomers to the EU (ibid.). Most applications were made in France $(47,800)$, Germany $(41,300)$, Sweden $(31,800)$, the UK $(22,100)$, and Belgium $(19,900)$ (OECD 2011, Table A.1.3., cited in Castles et al. 2014, 229). 
The 1992 Maastricht Treaty's abolition of borders considerably eased intra-EU movements (see also next sections of this chapter). At the same time, entrance into the EU became progressively restricted due to the unification of the European market, which imposed strict border controls and visa regulations. These controls on the entrance of foreigners went hand in hand with increased irregular migration (Bade 2003; Bonifazi 2008; Castles et al. 2014). Migrants' countries of origin as well as their migration motives became increasingly diversified.

[Nowadays migrants] come to Europe from all over the world in significant numbers: expatriates working for multinational companies and international organizations, skilled workers from all over the world, nurses and doctors from the Philippines, refugees and asylum seekers from African, near Eastern and Asian countries, from the Balkan and former Soviet Union countries, students from China, undocumented workers from African countries, just to single out some of the major immigrant categories (Penninx 2006, 8).

During this third period, integration issues became a central policy concern (see Doomernik \& Bruquetas in this volume). Many European countries stepped up attempts to attract highly skilled or educated migrants. This goal is still reflected in a number of national programmes today, for example, in Denmark, Germany, Sweden, and the UK. The EU established its Blue Card Scheme, an EU-wide residence and work permit (Eurostat 2011). Moreover, student migration from outside the EU became increasingly important in some parts of the EU (ibid.). Some countries' governments have actively recruited students with the intention of incorporating the "best and brightest" into their domestic labour market upon graduation (Lange 2013). Institutions of higher education have joined these efforts, stimulated by the economic benefits of attracting international students in the form of high tuition fees (Findlay 2011). In this context, several European countries, such as France, Germany, the Netherlands, and the UK simplified procedures for international students to make the education-to-work transition (Tremblay 2005; Van Mol 2014).

In the last section of this chapter, we differentiate between intra-EU mobility of European citizens and migration within and towards the EU of third-country nationals, as these groups are subject to different legislation. Intra-European mobility is often considered in positive terms, as contributing to the EU's 'vitality and competitiveness' (e.g., EC 2011, 3-4). European citizens, moreover, are entitled to move freely within the EU without the need for a visa, and hence may face fewer institutional barriers in migration trajectories. Migration into the EU, in contrast, remains largely associated with active measures of access restriction and border control (see, e.g., Council of the EU 2002). In recent decades, European migration policy has thus represented 'different intersecting regimes of mobility that normalise the movements of some travellers while criminalising and entrapping the ventures of others' (Glick Schiller and Salazar 2013, 189). The global economic crisis that started in 2008 might be considered the end of this third period, as it brought, at least temporarily, an end to 'rapid economic growth, EU expansion and high immigration' (Castles et al. 2014, 103). However, as Castles, De Haas and Miller (ibid.) observe, the decline in immigration from non-European countries has been rather modest, and the anticipated mass returns to migrants' home countries have not 
occurred as yet. The crisis mainly seems to have affected intra-European migration, with a decrease in overall free movement within the EU and with the peripheral countries hardest hit by the crisis - particularly Greece, Ireland, Italy, Portugal, and Spain—again becoming emigration countries (Castles et al. 2014).

\section{Migration Towards and from Europe}

We first analyse general trends in migration towards Europe, based on new estimates of global migration flows by Abel and Sander (2014). Their figures are based on stock statistics published by the United Nations. Note, however, that using stock data might be misleading for measuring flows. Furthermore, although the tables below represent the best estimates available, they are far from complete, as they are based on national statistics and thus reflect different legislation and definitions. This causes, for example, difficulties in comparability between countries as well as over time. The presented figures should thus be seen as indicative of larger patterns. The circular plots present migration flows from different world regions towards Europe and vice versa (Fig. 3.1) for four five-year periods between 1990 and 2010. Broader lines indicate more sizeable migration flows, while the arrow indicates the direction of the flow. As can be observed, migration from former Soviet Union countries to Europe gained momentum after the fall of the Berlin Wall but gradually decreased thereafter. Migration from Africa to Europe increased, especially in the mid-1990s. Furthermore, migration from East, South, and South-East Asia and from Latin America significantly rose, particularly after the start of the twenty-first century. Finally, migration from North America, Oceania, and West Asia remained relatively stable. Additional Eurostat data (not in the plots) show that between 2009 and 2012, the influx of non-EU migrants into the EU decreased slightly, from 1.4 million in 2009 to 1.2 million in 2012 (Eurostat 2014a).

In terms of the stock, $4 \%$ of the total EU population in 2013 was a non-EU national, accounting for about $6 \%$ of the EU's total working age population (Eurostat 2014a). Non-EU nationals were evenly split between men and women (ibid.). Note, however, that these data by nationality do not include all foreign-origin European residents (meaning those born abroad or having a foreign-born parent), as they cover only those who did not hold the nationality of the country they resided in. We further deconstruct these general trends below with a main focus on the last decade.

Looking at the top- 15 countries of origin of newly arrived immigrants in 2009 and 2012, we find large numbers of migrants from India and China, followed by Morocco and Pakistan (Table 3.3). Based on figures from 2008, the majority of Indian and Pakistani migrants seems to have headed to the UK. Most Chinese migrants seem to have gone to Spain (Eurostat 2011), and Moroccan migrants were mainly attracted to Italy and Spain.

In addition to the data on newly arriving immigrants (flow statistics), it is also relevant to know the main countries of origin of non-European migrants residing in the EU (stock statistics). When considering the top-10 countries of origin of non-EU 

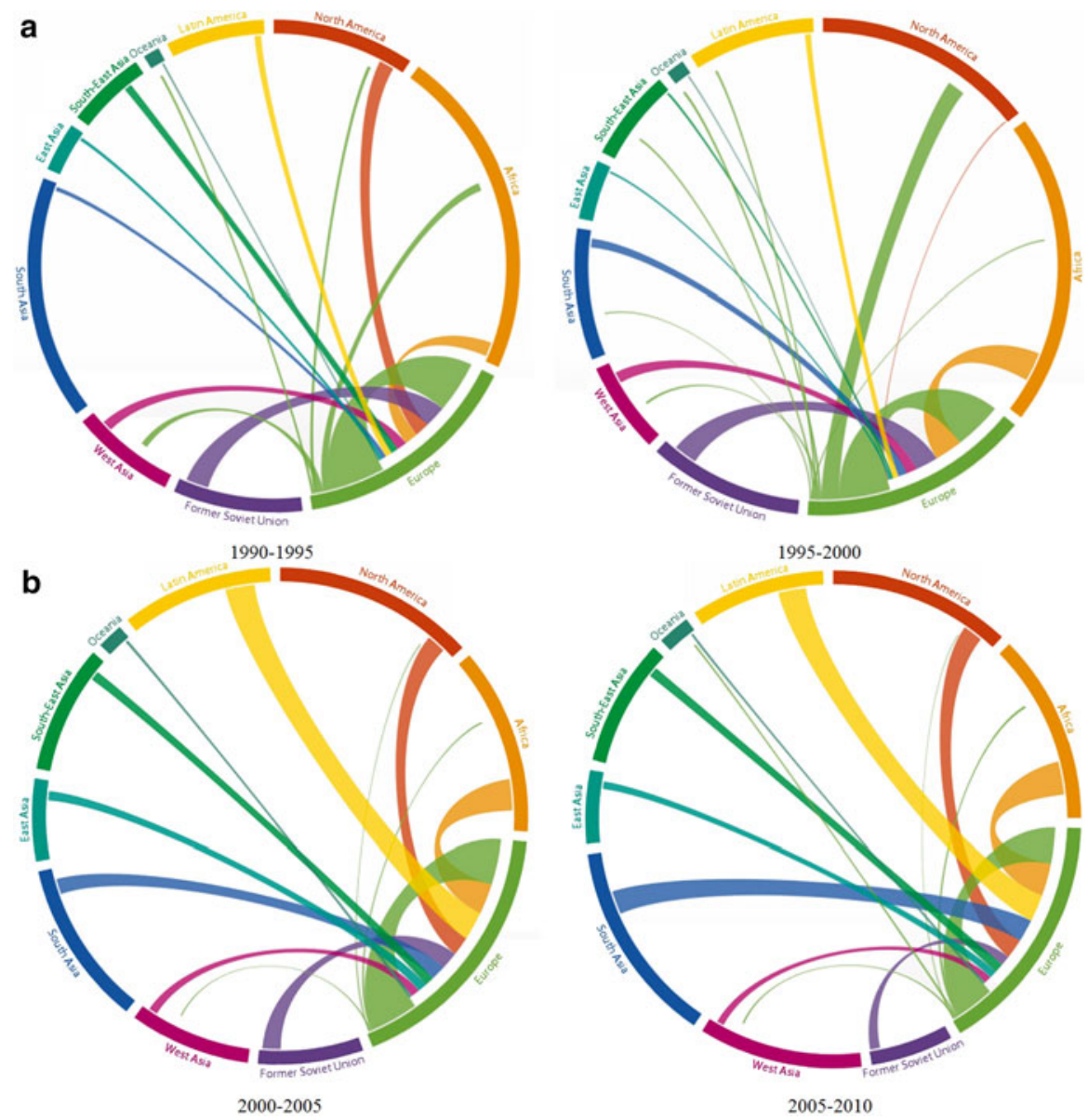

Fig. 3.1 Circular plots of migration flows towards and from Europe, per 5 year period between 1990 and 2010 (Source: www.global-migration.info)

nationals residing in the EU (Table 3.4), it can be noted that the largest residing populations are from countries where Europe recruited labour in the post-war period (Morocco and Turkey), as well as from former colonies (India and Pakistan), and countries near the EU's eastern border (Albania, Russia, and Serbia). The large Chinese diaspora is also prominent as well as the-mostly highly-skilled and lifestyle (Castles et al. 2014) —migrants from the USA.

Until the 1990s, the vast majority of migrants could conveniently be classified under the categories "family reunification", "labour migration", and "asylum". Since the 1990s, however, migration motives have become increasingly diversified, including a growing number of young people migrating to attend higher education. According to Eurostat (2014a), in 2012, 32 \% of migrants received a residence per- 
3 Migration and Immigrants in Europe: A Historical and Demographic Perspective

Table 3.3 Top- 15 countries of origin of newly arrived non-EU migrants in the EU, 2009 and 2012

\begin{tabular}{l|l|l|l|l}
\hline & 2009 & 2012 & \\
\cline { 2 - 5 } & Country of origin & $\begin{array}{l}\text { Number of } \\
\text { migrants }\end{array}$ & Country of origin & $\begin{array}{l}\text { Number of } \\
\text { migrants }\end{array}$ \\
\hline 1. & India & 92,575 & China (incl. Hong Kong) & 87,889 \\
\hline 2. & Morocco & 78,729 & India & 64,416 \\
\hline 3. & China (incl. Hong Kong) & 65,367 & Morocco & 53,121 \\
\hline 4. & Ukraine & 47,747 & Pakistan & 43,108 \\
\hline 5. & Pakistan & 35,969 & United States & 38,587 \\
\hline 6. & United States & 32,072 & Russia & 28,807 \\
\hline 7. & Philippines & 29,800 & Ukraine & 26,068 \\
\hline 8. & Albania & 28,153 & Nigeria & 21,130 \\
\hline 9. & Bangladesh & 25,611 & Australia & 19,331 \\
\hline 10. & Peru & 24,740 & Brazil & 18,307 \\
\hline 11. & Moldova & 24,222 & Albania & 16,775 \\
\hline 12. & Brazil & 24,204 & Philippines & 16,748 \\
\hline 13. & Colombia & 23,274 & Turkey & 16,198 \\
\hline 14. & Nigeria & 21,657 & Bangladesh & 13,880 \\
\hline 15. & Russia & 21,057 & Afghanistan & 13,060 \\
\hline
\end{tabular}

Source: Eurostat (2014a)

Note: Numbers refer to non-EU nationals whose previous place of residence was in a non-EU country and who had established their residence in a EU member state in the respective year

Table 3.4 Top-10 countries of nationality of non-EU migrants residing in the European Union, 2012

\begin{tabular}{l|l|l}
\hline & Country of origin & Number of migrants \\
\hline 1. & Turkey & $1,983,240$ \\
\hline 2. & Morocco & $1,384,935$ \\
\hline 3. & China (incl. Hong Kong) & 724,428 \\
\hline 4. & India & 650,710 \\
\hline 5. & Ukraine & 634,851 \\
\hline 6. & Russia & 589,634 \\
\hline 7. & Albania & 464,149 \\
\hline 8. & Serbia & 408,491 \\
\hline 9. & Pakistan & 407,133 \\
\hline 10. & United States & 406,266
\end{tabular}

Source: Eurostat (2014a)

Note: Numbers refer to non-EU nationals whose previous place of residence was in a non-EU country and who had established their residence in a EU member state for a period of at least 12 months 
mit for family reasons, $23 \%$ for work, $22 \%$ for education, and $23 \%$ for other reasons including asylum. Moreover, it should be noted that these categories report only the main migration motive as captured in the official statistics. In practice, these categories reflect migration motives as accepted in admission labels. Both may shift in the course of time. International students, for example, might become labour migrants upon graduation, and subsequently seek family reunification.

Lastly, migration is often not limited to moving from Country A to Country B but may involve several successive destinations. Considering intra-EU mobility of third-country nationals, an upward trend is observed between 2007 and 2011. This trend is most prominent in Germany, where the number of third-country nationals arriving from European Economic Area countries more than tripled, from 3784 in 2007 to 11,532 in 2011 (EMN 2013). A similar rise is also observed in the UK, where numbers increased from 1000 to 3000 (ibid.). Increases seem to be more modest in other EU countries, such as Austria (33.6\%), Finland (17.1\%), the Netherlands (53.7\%), and Sweden (30.2\%) (ibid.). However, whereas these percentages are high, absolute numbers are generally low. Compared with European citizens, intra-EU moves of third-country nationals are found to form only a small share of total intra-EU mobility between 2007 and 2011. The share of non-EU nationals in these movements barely surpasses $4 \%$ in the countries for which statistics are available: $1.8 \%$ in Germany, $3.6 \%$ in Austria, $3.7 \%$ in Finland, $2.3 \%$ in the Netherlands, and $1.2 \%$ in the UK (ibid.). Third-country nationals, moreover, move to geographically close countries, for example, from Germany and Italy to Austria, from Estonia and Sweden to Finland, from the Czech Republic and Germany to Poland, from Austria and the Czech Republic to Slovakia, and from Denmark and Germany to Sweden (ibid.). In sum, although it is often assumed that linear migration trajectories between two countries are less common now (see, e.g., Pieke et al. 2004), non-EU migrants do not seem to move frequently within the EU. This might be due to the legal restrictions often imposed on this group of migrants, or it could be more related to factors such as language similarities between bordering countries (De Valk and Díez Medrano 2014).

\section{Mobility of EU Citizens}

\section{Numbers and Destinations}

Previous studies indicate that only a small share of the European population is mobile (Bonin et al. 2008; Pascouau 2013). Favell and Recchi (2009), for example, show that less than one in fifty Europeans lives abroad, and around $4 \%$ have some experience of living and working abroad. Nevertheless, the scale of intra-EU mobility clearly increased between 2000 and 2011 (Fig. 3.2). Data from Eurostat (2011), for example, show that nearly 2 million EU citizens moved within the EU in 2008. In absolute numbers, Polish migration made up the greatest share of intra-EU flows in the first decade of the twenty-first century (Fig. 3.2). Migration between Poland 


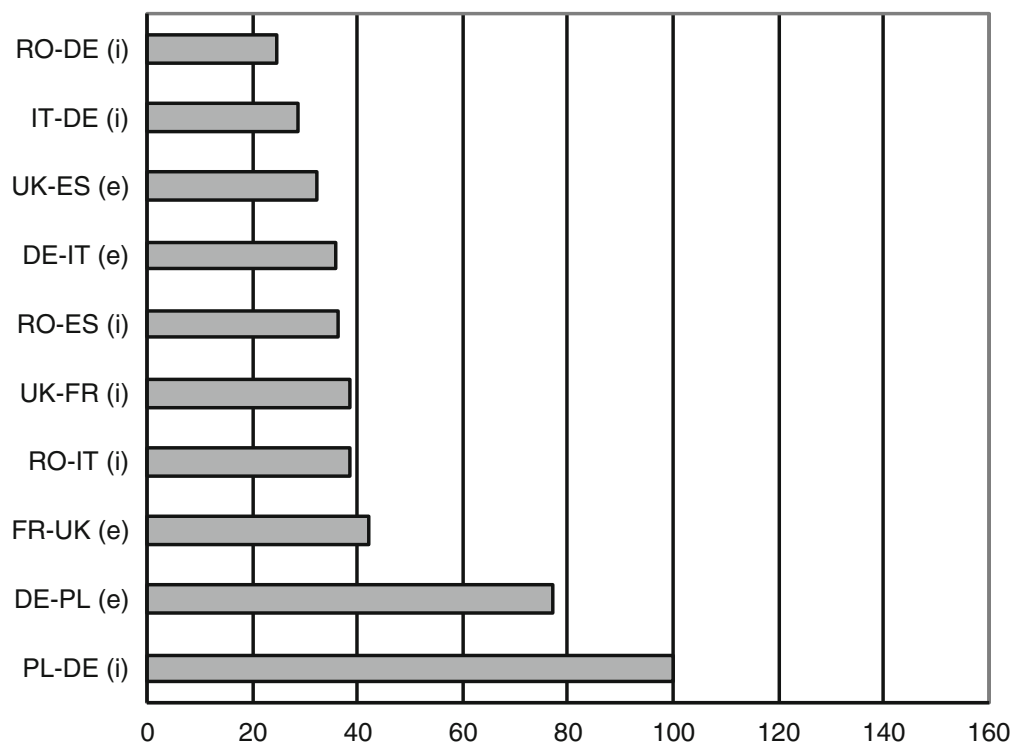

$\mathrm{i}=$ according to country of immigration; $\mathrm{e}=$ according to country of emigration;

DE: Immigration 2000-2003 = 2000, 2002, and 2003;

FR: Immigration and emigration 2000-2003 = 2002-2003;

IT: Immigration and emigration 2000-2003 = 2001-2003;

ES: Emigration 2000-2003 = 2002-2003

Data source: Eurostat, own calculations by NIDI

b

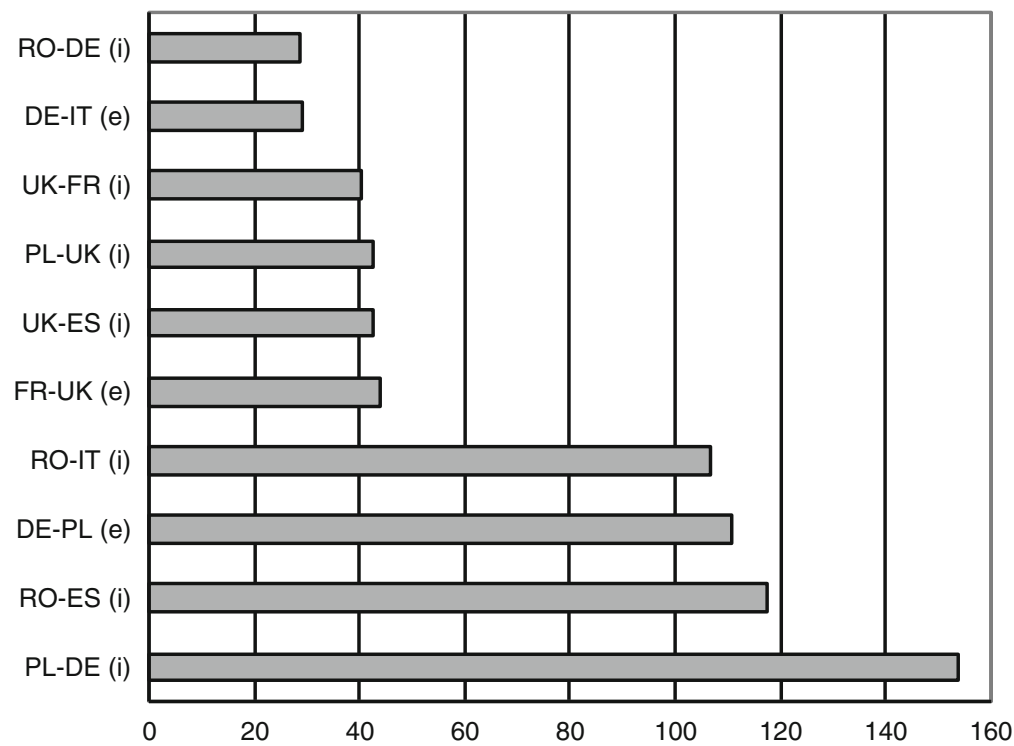

$\mathrm{i}=$ according to country of immigration; $\mathrm{e}=$ according to country of emigration UK: Immigration 200-42007=2004-2006

Data source: Eurostat

Fig. 3.2 Top-ten intra-European migration flows, 2000-2011 (absolute numbers) 
C

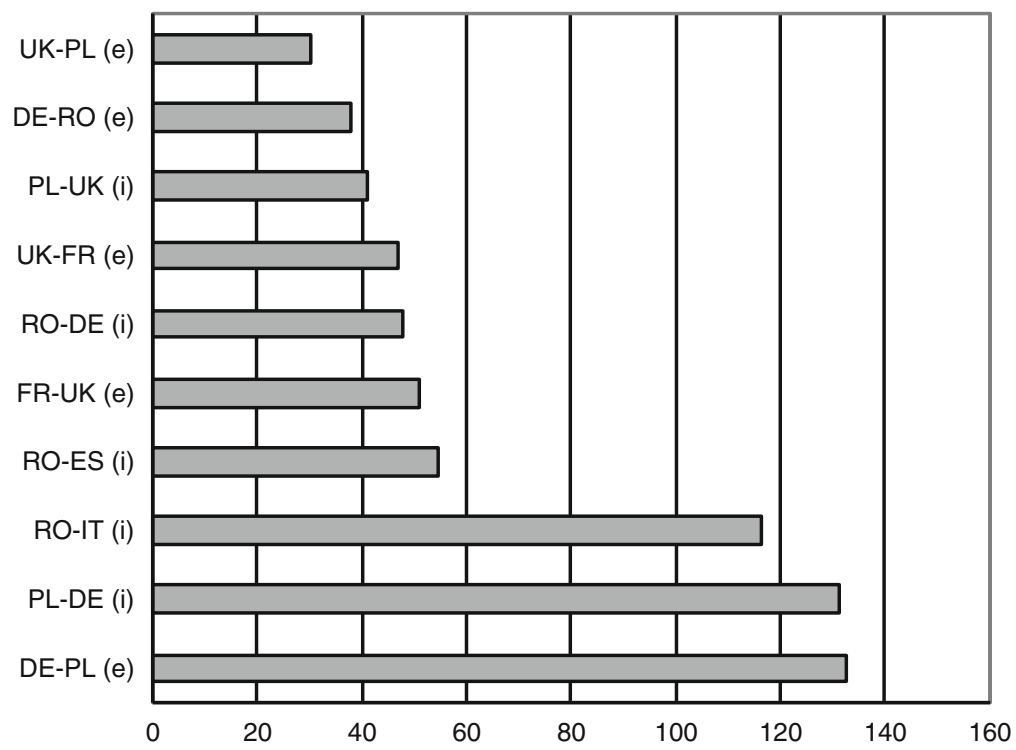

$\mathrm{i}=$ according to country of immigration; $\mathrm{e}=$ according to country of emigration

DE: Immigration and emigration 2008-2011=2008

FR: Immigration and emigration 2008-2011 $=2008$

UK: Immigration and emigration 2008-2011=depending on varying availability of data

Data source: Eurostat

Fig. 3.2 (continued)

and Germany was most prevalent, and consists of movements from as well as to Poland. The prevalence of Polish-German migration might be explained by the fact that such migration has been regulated since 1990, when the German and Polish governments signed a bilateral agreement allowing Polish citizens to engage in legal seasonal employment for 3 months in specific sectors of the German economy (Dietz and Kaczmarczyk 2008). This led to a sharp increase in the inflow of Polish seasonal workers in Germany, from approximately 78,600 in 1992 to 280,000 in 2002 (ibid.). From 2004 to 2007, after Poland's EU accession, we observe a similar increase in population movements from Poland to the UK. This can be attributed to the fact that - unlike other EU member states-Ireland, Sweden, and the UK did not restrict migration from the new member states. Of these three destinations, Ireland and the UK were the most popular, in part due to favourable labour market conditions (Castles et al. 2014). In more recent years, however, many Polish migrants have left the UK, indicating increasing return migration, perhaps related to the economic crisis, as the Polish economy has kept growing (Castles et al. 2014). Apart from the migration flows from and towards Poland, similar inflows and outwards movements from Romania were observed between 2000 and 2011. Whereas 
between 2000 and 2003 some 39,000 Romanians migrated to Italy and Spain, these numbers increased to about 110,000 in the subsequent years. Furthermore, Romanian migration to Italy remained relatively stable, in sharp contrast with the migration flow towards Spain, which dropped sharply between 2008 and 2011. This can be attributed to the more difficult labour market conditions in Spain, because of the economic crisis, which has redirected the movement of Romanian migrants towards other EU countries (OECD 2013).

Besides migration between Eastern Europe and several other EU countries, migration flows have been considerable between the UK, France, and Spain. These movements likely include retirement migration from Northern to Southern Europe, but also point to increased labour mobility between these countries, especially considering the flows towards the UK, as will be further discussed later.

Finally, in recent years, the global economic crisis seems to have impacted patterns of intra-EU migration. Data from the OECD (2013) show, for example, an increase in emigration from countries heavily affected by the crisis (Table 3.5). Cases in point are Greece and Spain where unemployment rose to unprecedented levels-27.3\% in Greece and $26.1 \%$ in Spain in 2013, with youth unemployment rates of, respectively, 58.3 and $55.5 \%$ that same year (Eurostat 2014b). Countries that eased their way into economic recovery, such as Iceland and Ireland, have already registered declines in the numbers of individuals leaving these countries (OECD 2013). Belgium, Germany, the Netherlands, and the UK appear to be popular destination countries, as intra-European migration flows towards these countries almost doubled in the 5 years prior to 2012. The crisis, however, also led to migration to

Table 3.5 Migration from specific European countries to main European and other OECD destination countries, 2007-2011

\begin{tabular}{l|l|l|l|l|l|l}
\hline & & & Index & & & Number (thousands) \\
\cline { 2 - 8 } & 2007 & 2008 & 2009 & 2010 & 2011 & 2011 \\
\hline Country of origin & 100 & 106 & 102 & 143 & 236 & 39 \\
\hline Greece & 100 & 111 & 163 & 165 & 135 & 4 \\
\hline Iceland & 100 & 104 & 174 & 210 & 181 & 21 \\
\hline Ireland & 100 & 116 & 111 & 132 & 142 & 85 \\
\hline Italy & 100 & 120 & 98 & 103 & 125 & 55 \\
\hline Portugal & 100 & 114 & 123 & 173 & 224 & 72 \\
\hline Spain & 100 & 105 & 116 & 133 & 188 & 78 \\
\hline Country of destination & 100 & 120 & 113 & 174 & 195 & 88 \\
\hline Germany & 100 & 116 & 96 & 102 & 121 & 33 \\
\hline United Kingdom & 100 & 142 & 146 & 169 & 193 & 15 \\
\hline Switzerland & 100 & 138 & 144 & 157 & 184 & 12 \\
\hline Belgium & 100 & 109 & 116 & 124 & 129 & 50 \\
\hline Netherlands & 100 & 115 & 114 & 140 & 165 & 275 \\
\hline All other OECD countries & \multicolumn{7}{|l}{} \\
\hline Total & \multicolumn{7}{|l|}{} &
\end{tabular}

Source: OECD $(2013,23)$ 


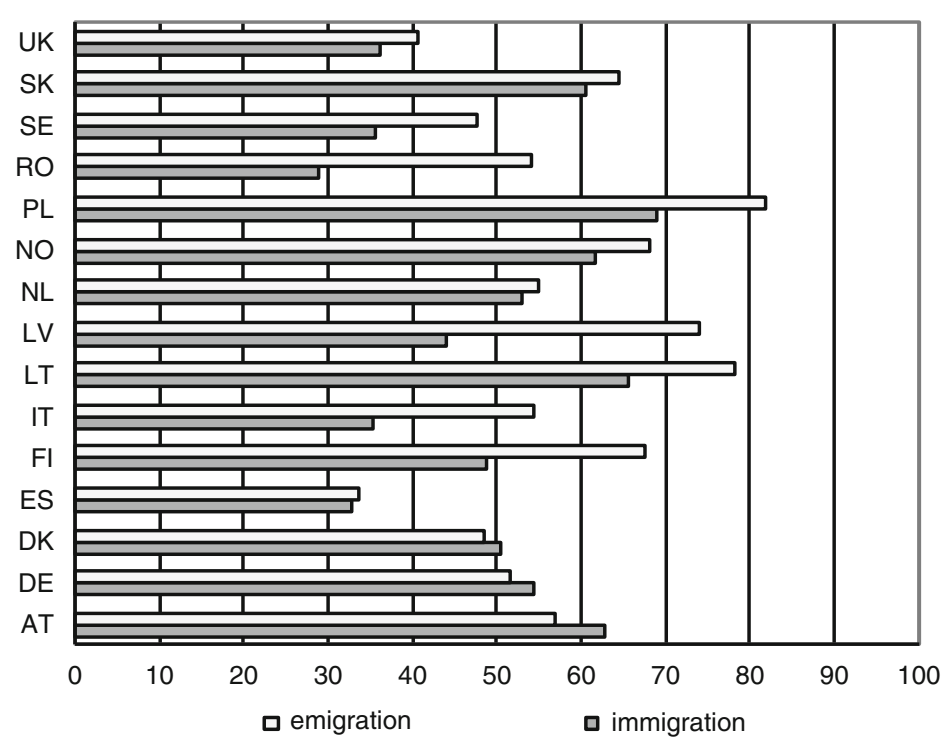

PL: immigration 2008-2011 = 2008 and 2010; emigration 2008-2011 = 2008;

RO: emigration 2008-2011 = 2008

(Source: Eurostat, own calculations by NIDI)

Fig. 3.3 Share of intra-European migrants in total emigration and immigration for selected European countries, 2008-2011 (\%)

non-European countries, such as Argentina, Australia, Brazil, China, Turkey, the USA, and in the case of Portugal, to former colonies in Africa (Castles et al. 2014).

It is important to keep in mind that most of the previous analyses are based on absolute numbers, whereby EU member states with larger populations are logically more visible. We now consider the relative importance of migration flows as a share of countries' total immigration and emigration figures. Figure 3.3 shows the relative share of EU migration for selected EU countries.

Intra-EU migration forms a substantial share of movements to and from the majority of the countries in Fig. 3.3. Based on these numbers, we can discern several groups. The first group consists of countries where intra-EU immigration and emigration comprises the largest share of migration movements. It includes Austria, Germany, Lithuania, the Netherlands, Norway, Poland, Slovakia, and Denmark. The attraction of these countries is explained by their well-developed economies. Particularly significant within this group are Polish and Lithuanian migrants moving on to other European destinations. The second group is made up of countries where more than half of emigration moves are directed towards other European countries, and immigration is mostly non-European. This group is comprised of Finland, Italy, Latvia, and Romania. Their geographical location at the borders of Europe might explain this pattern, as these countries receive immigrants from neighbouring (non-European) countries and function as transit countries. 
Furthermore, these countries might be less attractive to migrants from other EU countries because of their limited economic opportunities and relatively low wages (except for Finland). The third group consists of countries where both emigration and immigration from and to non-European countries is still of considerable importance. This group includes Spain, Sweden, and the UK. For Sweden, the most popular destinations for migrants are (besides the Nordic neighbours) English-speaking countries such as the UK and the USA (Mannheimer 2012). In terms of the arriving population, humanitarian refuge and family reunification are the main channels of immigration in Sweden, which explains the large share of non-European migrants (Fredlund-Blomst 2014). Spain's and the UK's migration balances might reflect continuing migration from former colonies and historical links with various world regions which include, for example, language similarities. The UK attracts a considerable number of migrants from ex-colonies such as India and Pakistan (Office for National Statistics 2011). Furthermore, the principal non-European destinations for UK migrants are English-speaking countries such as Australia, Canada, New Zealand, and the USA (Murray et al. 2012). For Spain, non-European migrants mainly originate from Morocco and Latin American countries, and Spanish migrants emigrate to Latin American countries such as Argentina and Venezuela (INE 2014).

\section{Demographic Characteristics of Intra-EU Movers}

It has been suggested that free movement within the EU is particularly availed of by the highly educated (Favell 2008). We therefore investigate the demographic characteristics of those who move within Europe, focusing on selected cases and the period 2008-2011. Contrasting these cases, for which we have detailed information, suggests the diversity of migration flows and motives within Europe. Obviously this analysis does not do justice to more recent moves from Southern Europe to NorthWestern Europe, but data to make similar analyses are not yet at hand.

We start with characteristics of those who move. Figure 3.4 shows population pyramids for Polish migrants heading to Germany and vice versa. As we demonstrated previously (see Fig. 3.2), Polish-German migration is the most prominent intra-European migration flow in absolute numbers. The population pyramids are indicative of the trend in the preceding years. Mobility between both countries is clearly dominated by men, particularly those between 20 and 50 years of age. This strongly male-dominated movement of Polish workers towards Germany appears temporary, as a similar population moves back again (compare Fig. 3.4a and b).

When we compare Polish migration to Germany with Polish migration to the Netherlands, we find a different panorama (Fig. 3.5). Polish migrants in the Netherlands are significantly younger, the majority being between 20 and 35 years of age. Moreover, there is a more equal gender balance. The coincidence of these migration flows with other life transitions, such as having children and forming a union, is crucial to gain insight into the way intra-European mobility develops over the life course. 
Recent research on Polish migrants based on Dutch population registers shows that having children as well as the choice of partner are important determinants of permanent settlement (Kleinepier et al. 2015). Similar findings have been reported on intra-EU migrant groups in other destinations such as Belgium and the UK (see, e.g., Levrau et al. 2014; Ryan and Mulholland 2013). Where generally circular and return migration of intra-EU movers is high, this seems especially so for those who are young, single, and do not have children (see, e.g., Bijwaard 2010; Braun and Arsene 2009; Kleinepier et al. 2015; Nekby 2006).

The relationship between life course and migration becomes more apparent when we compare migrants from Romania and those from the UK residing in Spain (Fig. 3.6). Romanian migration to Spain is clearly dominated by young people, with an overrepresentation of the 20-24 year category. Most of these men and women arrived in Spain for work or study. The population pyramid of British residents in Spain has a totally different structure. Some of the British migrants are 30-40 years old, and many are in the older age groups, from 55 years and older. Thus, British migrants in Spain seem to be free movers coming to work in Spain alongside retirement migrants.

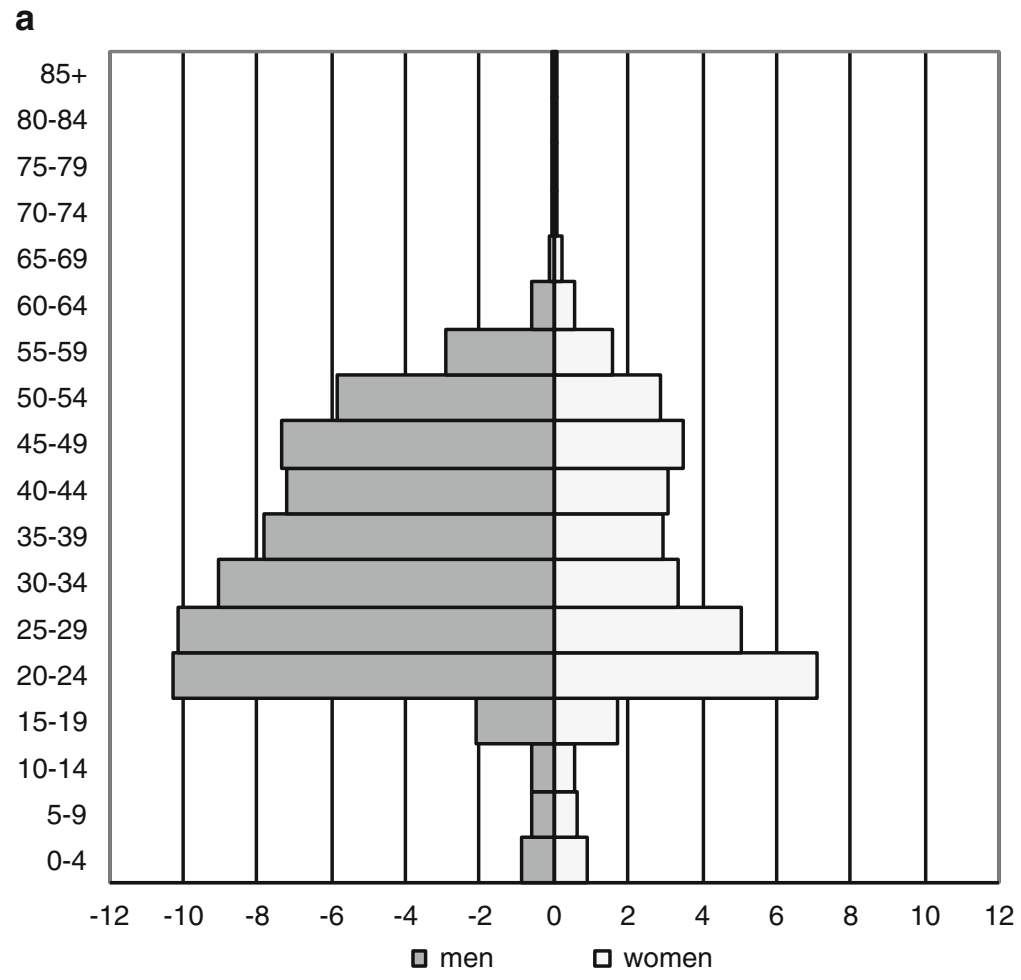

Data source: Eurostat; calculations by NIDI

Fig. 3.4 Population pyramid of migrants from Poland to Germany (a) and Germany to Poland (b), $2008(\%)$ 


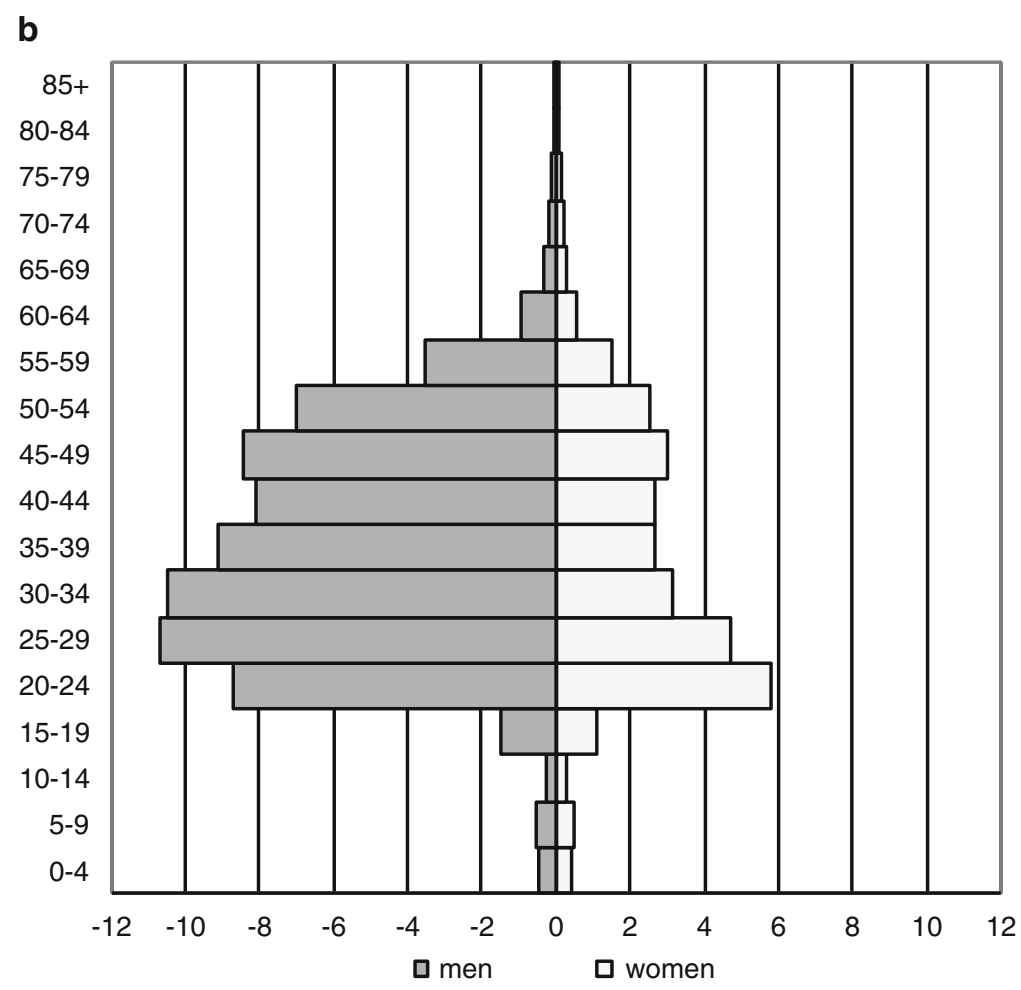

Data source: Eurostat; calculations by NIDI

Fig. 3.4 (continued)

In sum, patterns of intra-EU migration are becoming increasingly diverse. European citizens enjoy the right of freedom of movement, and might decide to temporarily or permanently settle in another European country for a variety of reasons, including family formation, retirement, study, and work. Finally it is crucial to realize that categorization of migrants into certain migration motives is rather difficult as very often multiple different reasons overlap (see, e.g., Gilmartin and Migge 2015; Santacreu et al. 2009; Verwiebe 2014).

\section{Conclusions}

In this chapter we addressed the first key actor of the binomials presented in Chap. 1 of this volume, namely migrants themselves. We first of all presented a historical overview of trends in international migration to and within Europe since the 1950s. Furthermore, we examined the demographic characteristics of these migration flows 


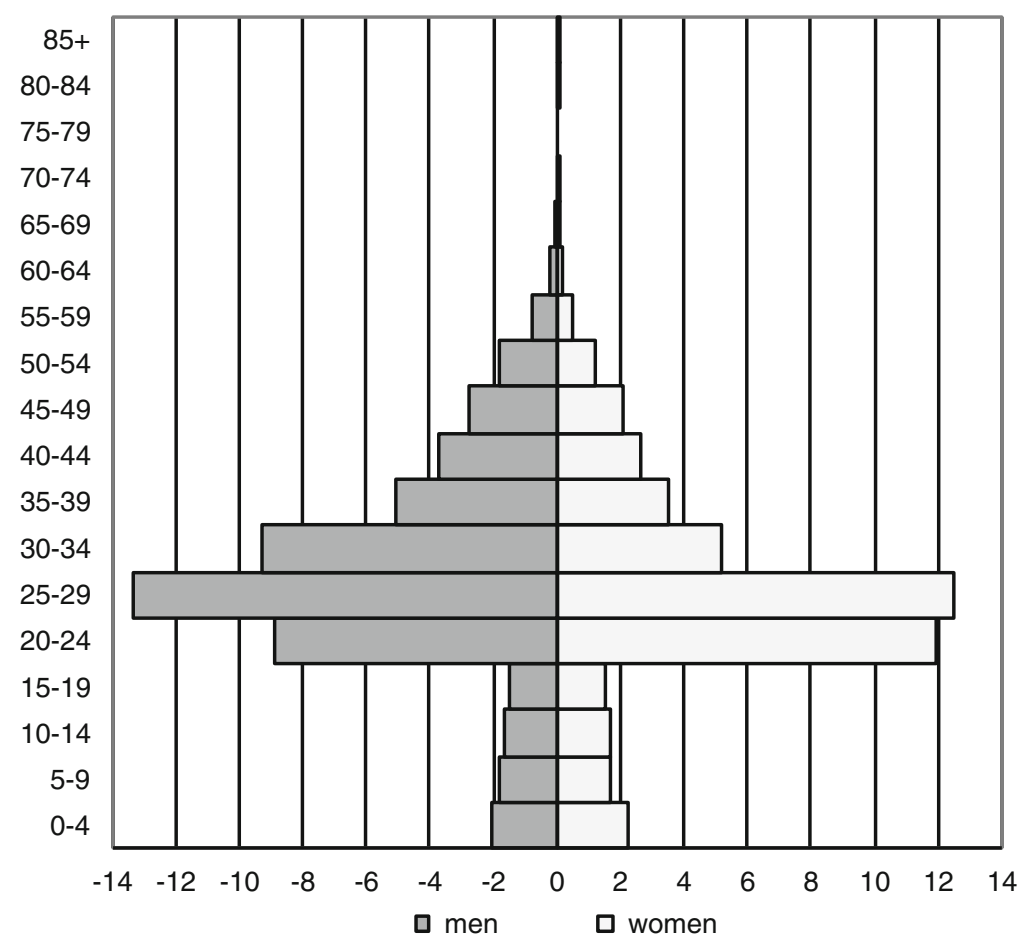

NB. NL 2009: break in series due to new regulation

Data source: Eurostat; calculations by NIDI

Fig. 3.5 Population pyramid of Polish migrants to the Netherlands, 2009 (\%)

as well as the characteristics of residing migrants across Europe using recent data. We looked at both immigration and emigration in the European context to do sufficient justice to the dynamic nature of migration. Yet, our findings provide only a general overview, as the complexity of migration to and from Europe extends well beyond the scope of a single chapter. Three historical periods were distinguished. It is important to bear these different periods in mind when studying current migration flows in Europe. They help to frame but also for analysing the (demographic) behaviour of migrant populations. The distinguished periods may help us to structure and understand the socio-demographic situations which migrants face today. In addition, this distinction into different periods enables us to appreciate the current and ongoing political and public debates on migration in Europe.

The first period was characterized by labour migration and a favourable stance towards migration, covering the years from the beginning of the bilateral guest worker agreements until the oil crisis. European governments first recruited guest workers in Southern Europe, but quickly expanded towards countries at Europe's borders. Apart from labour migration, a significant postcolonial migration flow char- 
acterized this period. Due to struggles for independence in former colonies, many European countries received return migrants as well as migrants fleeing hostile conflict environments. The Cold War limited East-West mobility during this period.

The second period extended from the oil crisis in the early 1970s to the fall of the Iron Curtain in the late 1980s. It was characterized by a cessation of guest worker migration and stringent entry restrictions for new migrants. Nevertheless, migration flows were transformed rather than halted. Whereas previously labour migration had been the main migration channel, family reunification (and family formation) now took over the primary role, and asylum applications were also on the rise. European governments became aware that migrant populations were likely to remain on their territory, and they slowly began to develop integration policies. This continues to be an important issue in the discourse today.

The third period dates from the 1990s to the present day. During this time, we find substantial diversification in terms of countries of origin, destinations, flows, migration motives, and structure of migrant populations. One of the most important elements in this period has been the removal of barriers to intra-European mobility, while migration into the EU has become more restricted. As such, intra-EU mobility

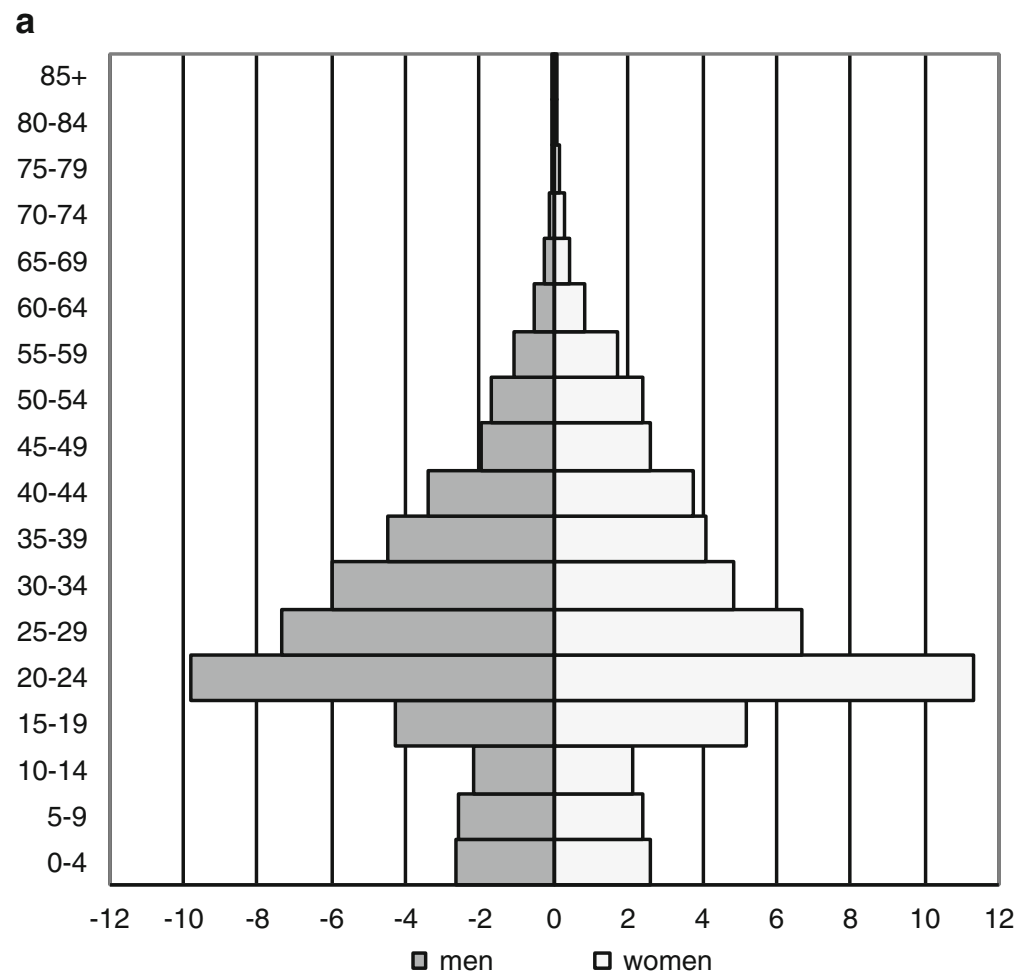

Data source: Eurostat; calculations by NIDI

Fig. 3.6 Population pyramid of Romanian (a) and British (b) migrants in Spain, 2008-2011 (\%) 


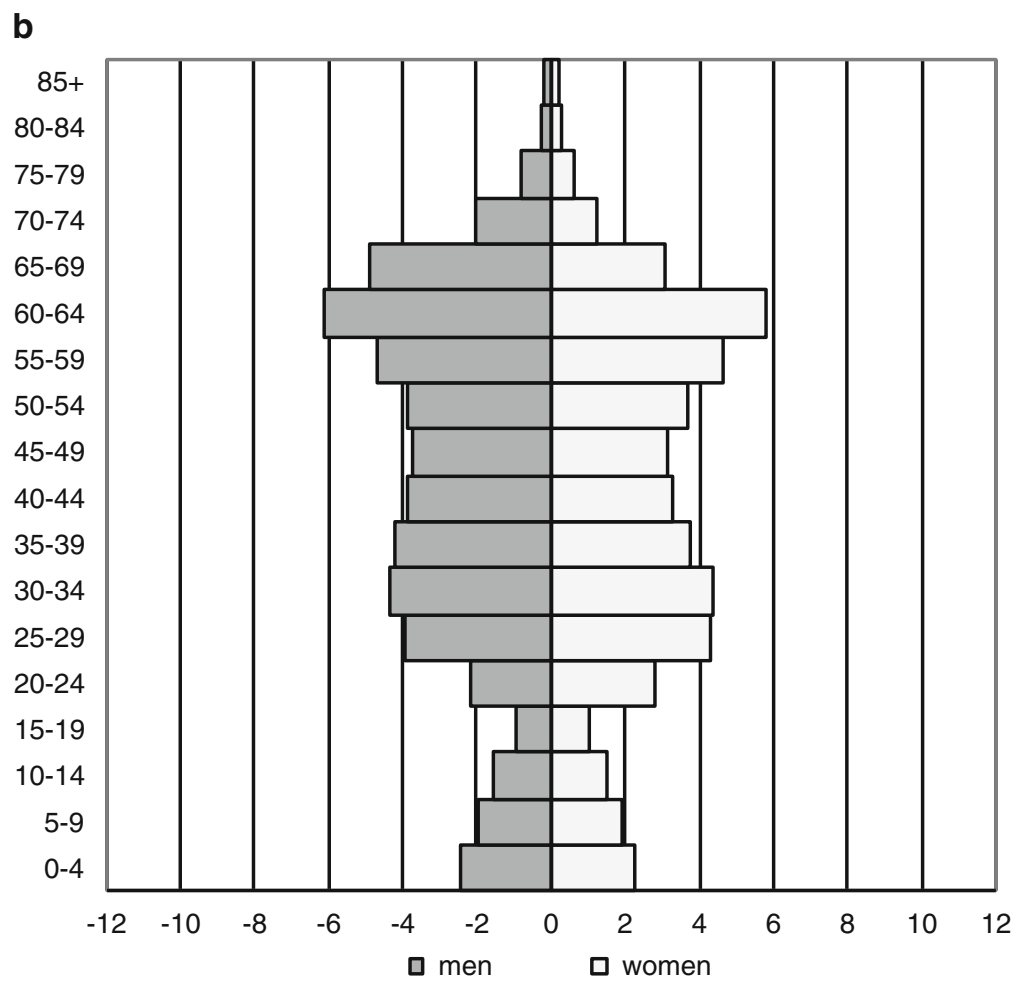

Data source: Eurostat; calculations by NIDI

Fig. 3.6 (continued)

and migration into the EU have become embedded in different and often opposing discourses. The end of this third period might be the economic crisis, which so far seems to have affected mainly intra-European mobility patterns. Peripheral countries have been hit particularly hard by the crisis, and an increasing tendency towards emigration can be observed from countries such as Greece, Ireland, Italy, Portugal, and Spain. Immigration of non-EU migrants, however, seems less affected. This is perhaps because many migrants from outside Europe have found other routes of arrival, including irregular entrance and stay. Moreover, European countries are interested in highly skilled migrants in the context of a global competition for talent.

As a result, it seems that comparable to the "migration stop" after the oil crisis of the 1970s or during the Cold War, migration towards Europe will be transformed rather than come to a complete halt in the coming years. Mobility within Europe, in this regard, cannot be seen as separate from migration from outside the EU. Studying migration systems rather than focusing exclusively on one aspect of mobility is thus called for. At the same time, our analyses in this chapter also suggest an increasing dichotomy between migrants who are in a favourable situation with easy access and rights in Europe (e.g., EU free movers and highly skilled migrants) and those in less 
favourable situations (mainly those arriving from outside Europe for other reasons). Development of this dichotomy has important consequences for the lives of individual migrants and for social cohesion. European societies must demonstrate awareness of this with policies crafted to acknowledge the diverse nature and dynamic character of migration that we have shown in this chapter.

Acknowledgments This research was part of and supported by the European Research Council Starting Grant project (no. 263829) "Families of Migrant Origin: A Life Course Perspective".

Open Access This chapter is distributed under the terms of the Creative Commons AttributionNoncommercial 2.5 License (http://creativecommons.org/licenses/by-nc/2.5/) which permits any noncommercial use, distribution, and reproduction in any medium, provided the original author(s) and source are credited.

The images or other third party material in this chapter are included in the work's Creative Commons license, unless indicated otherwise in the credit line; if such material is not included in the work's Creative Commons license and the respective action is not permitted by statutory regulation, users will need to obtain permission from the license holder to duplicate, adapt or reproduce the material.

\section{References}

Abel, G. J. (2010). Estimation of international migration flow tables in Europe. Journal of the Royal Statistical Society: Series A (Statistics in Society), 173(4), 797-825.

Abel, G. J., \& Sander, N. (2014). Quantifying global international migration flows. Science, 343(6178), 1520-1522.

Bade, K. J. (2003). Europa en movimiento: Las migraciones desde finales del siglo XVIII hasta nuestros días. Barcelona: Crítica.

Barou, J. (2006). Europe, terre d'immigration: Flux migratoires et intégration. Grenoble: Presses Universitaires de Grénoble.

Bijwaard, G. (2010). Immigrant migration dynamics model for the Netherlands. Journal of Population Economics, 23(4), 1213-1247.

Bonifazi, C. (2008). Evolution of regional patterns of international migration in Europe. In C. Bonifazi, M. Okólski, J. Schoorl, \& P. Simon (Eds.), International migration in Europe: New trends and new methods of analysis (IMISCOE research, pp. 107-128). Amsterdam: Amsterdam University Press.

Bonin, H., Eichhorst, W., Florman, C., Okkels Hansen, M., Skiöld, L., Stuhler, J., Tatsiramos, K., Thomasen, H., \& Zimmerman, K. F. (2008). Geographic mobility in the European Union: Optimising its economic and social benefits. IZA research report 19. Bonn: Institute for the Study of Labor.

Boyle, P., Halfacree, K., \& Robinson, V. (1998). Exploring contemporary migration. Essex: Pearson Education Limited.

Braun, M., \& Arsene, C. (2009). The demographics of movers and stayers in the European Union. In E. Recchi \& A. Favell (Eds.), Pioneers of European integration: Citizenship and mobility in the EU (pp. 26-51). Cheltenham: Edward Elgar.

Castles, S., Booth, H., \& Wallace, T. (1984). Here for good: Western Europe's new ethnic minorities. London: Pluto Press.

Castles, S., De Haas, H., \& Miller, M. J. (2014). The age of migration: International population movements in the modern world. Basingstoke: Palgrave Macmillan.

Council of the EU. (2002). Seville European Council 21 and 22 June 2002: Presidency conclusions. Brussels: European Commission. 
De Valk, H. A. G., \& Díez Medrano, J. (2014). Guest editorial on meeting and mating across borders: Union formation in the European Union single market. Population, Space and Place, 20(2), 103-109.

Dietz, B. (2006). Aussiedler in Germany: From smooth adaptation to tough integration. In L. Lucassen, D. Feldman, \& J. Oltmer (Eds.), Paths of integration: Migrants in Western Europe, 1880-2004 (pp. 116-136). Amsterdam: Amsterdam University Press.

Dietz, B., \& Kaczmarczyk, P. (2008). On the demand side of international labour mobility: The structure of the German labour market as a causal factor of seasonal Polish migration. In C. Bonifazi, M. Okólski, J. Schoorl, \& P. Simon (Eds.), International migration in Europe: New trends and new methods of analysis (IMISCOE research, pp. 37-64). Amsterdam: Amsterdam University Press.

EC. (2011). The global approach to migration and mobility. COM(2011) 743 final. Brussels: European Commission.

EMN. (2013). Intra-EU mobility of third-country nationals. Brussels: European Migration Network.

Eurostat. (2011). Migrants in Europe: A statistical portrait of the first and second generation. Luxembourg: Publications Office of the European Union.

Eurostat. (2014a). Immigration in the EU. Brussels: European Commission.

Eurostat. (2014b). Unemployment Statistics. Brussels: European Commission. http://epp.eurostat. ec.europa.eu/statistics_explained. Accessed 8 Aug 2014.

Fassmann, H., \& Münz, R. (1992). Patterns and trends of international migration in Western Europe. Population and Development Review, 18(3), 457-480.

Fassmann, H., \& Münz, R. (1994). European East-West migration, 1945-1992. International Migration Review, 28(3), 520-538.

Favell, A. (2008). Eurostars and Eurocities: Free movement and mobility in an integrating Europe. Malden/Oxford: Blackwell Publishing.

Favell, A., \& Recchi, E. (2009). Pioneers of European integration: An introduction. In E. Recchi \& A. Favell (Eds.), Pioneers of European integration: Citizenship and mobility in the EU (pp. 1-25). Cheltenham: Edward Elgar.

Findlay, A. M. (2011). An assessment of supply and demand-size theorizations of international student mobility. International Migration, 49(2), 183-200.

Fredlund-Blomst, S. (2014). Assessing immigrant integration in Sweden after the May 2013 riots. www.migrationpolicy.org. Accessed 13 Aug 2014.

Gilmartin, M., \& Migge, B. (2015). European migrants in Ireland: Pathways to integration. European Urban and Regional Studies, 22(3), 285-299.

Glick Schiller, N., \& Salazar, N. B. (2013). Regimes of mobility across the globe. Journal of Ethnic and Migration Studies, 39(2), 183-200.

Goldscheider, C., Bernhardt, E., \& Goldscheider, F. (2008). What integrates the second generation? Factors affecting family transitions to adulthood in Sweden. In C. Bonifazi, M. Okólski, J. Schoorl, \& P. Simon (Eds.), International migration in Europe: New trends and new methods of analysis (IMISCOE research, pp. 226-245). Amsterdam: Amsterdam University Press.

Hansen, R. (2003). Migration to Europe since 1945: Its history and its lessons. The Political Quarterly, 74(s1), 25-38.

Hatton, T. (2004). Seeking asylum in Europe. Economic Policy, 19(38), 5-62.

Hoerder, D. (2002). Cultures in contact: World migrations in the second millennium. Durham/ London: Duke University Press.

INE (Instituto Nacional de Estadística). (2014). Estadística del padrón de Españoles residentes en el extranjero: Datos a 1-1-2014. www.ine.es. Accessed 14 Aug 2014.

Kleinepier, T., De Valk, H. A. G., \& Van Gaalen, R. (2015). Life paths of Polish migrants in the Netherlands: Timing and sequencing of events. European Journal of Population, 31(2), 155-179.

Kupiszewska, D., \& Nowok, B. (2008). Comparability of statistics on international migration flows in the European union. In J. Raymer \& F. Willekens (Eds.), International migration in Europe: Data, models and estimates (pp. 41-71). Chichester: Wiley. 
Lange, T. (2013). Return migration of foreign students and non-resident tuition fees. Journal of Population Economics, 26(2), 703-718.

Levrau, F., Piqueray, E., Goddeeris, I., \& Timmerman, C. (2014). Polish immigration in Belgium since 2004: New dynamics of migration and integration? Ethnicities, 14(2), 303-323.

Mannheimer, L. (2012). Fler utvandrare än på 1800-talet, Dagens Nyhet. 20 Feb.

Münz, R., \& Ulrich, R. (1998). Germany and its immigrants: A socio-demographic analysis. Journal of Ethnic and Migration Studies, 24(1), 25-56.

Murray, R., Harding, D., Angus, T., Gillespie, R., \& Arora, H. (2012). Emigration from the UK (Research report 68). London: Home Office.

Nekby, L. (2006). The emigration of immigrants, return vs onward migration: Evidence from Sweden. Journal of Population Economics, 19(2), 197-226.

Nowok, B., Kupiszewska, D., \& Poulain, M. (2006). Statistics on international migration flows. In M. Poulain, N. Perrin, \& A. Singleton (Eds.), THESIM: Towards harmonised European statistics on international migration (pp. 203-231). Louvain-la-Neuve: Presses Universitaires de Louvain.

OECD. (2011). International migration outlook 2011. Paris: Organisation for Economic Cooperation and Development.

OECD. (2013). International migration outlook 2013. Paris: Organisation for Economic Cooperation and Development.

Office for National Statistics. (2011). Migration statistics quarterly report, November 2011. London: Office for National Statistics.

Okólski, M. (2012). Transition from emigration to immigration: Is it the destiny of modern European societies? In M. Okólski (Ed.), European immigrations: Trends, structures and policy implications (IMISCOE research, pp. 23-44). Amsterdam: Amsterdam University Press.

Page Moch, L. (2003). Moving Europeans: Migration in Western Europe since 1650. Bloomington: Indiana University Press.

Pascouau, Y. (2013). Intra-EU mobility: The "second building block" of EU labour migration policy (Issue paper no. 74). Brussels: European Policy Centre.

Penninx, R. (2006). Introduction. In R. Penninx, M. Berger, \& K. Kraal (Eds.), The dynamics of international migration and settlement in Europe: A state of the art (IMISCOE joint studies, pp. 7-17). Amsterdam: Amsterdam University Press.

Pieke, F., Nyiri, P., Thuno, M., \& Ceccagno, A. (2004). Transnational Chinese: Fujianese migrants in Europe. Stanford: Stanford University Press.

Poulain, M., Perrin, N., \& Singleton, A. (Eds.). (2006). THESIM: Towards harmonised European statistics on international migration. Louvain-la-Neuve: Presses Universitaires de Louvain.

Raymer, J., De Beer, J., \& Van der Erf, R. (2011). Putting the pieces of the puzzle together: Age and sex-specific estimates of migration amongst countries in the EU/EFTA, 2002-2007. European Journal of Population, 27(2), 185-215.

Ryan, L., \& Mulholland, J. (2013). Trading places: French highly skilled migrants negotiating mobility and emplacement in London. Journal of Ethnic and Migration Studies, 40(4), 584-600.

Santacreu, O., Baldoni, E., \& Albert, M. C. (2009). Deciding to move: Migration projects in an integrating Europe. In E. Recchi \& A. Favell (Eds.), Pioneers of European integration: Citizenship and mobility in the EU (pp. 52-71). Cheltenham: Edward Elgar.

Tremblay, K. (2005). Academic mobility and immigration. Journal of Studies in International Education, 9(3), 196-228.

UNCHR. (2001). Asylum applications in industrialised countries, 1980-1999. Geneva: United Nations High Commissioner for Refugees.

Van Mol, C. (2014). Intra-European student mobility in international higher education circuits: Europe on the move. Basingstoke: Palgrave Macmillan.

Verwiebe, R. (2014). Why do Europeans migrate to Berlin? Social-structural differences for Italian, British, French and Polish nationals in the period between 1980 and 2002. International Migration, 52(4), 209-230.

Vilar, J. B. (2001). Las emigraciones Españolas a Europa en el siglo XX: Algunas cuestiones a debater. Migraciones \& Exilios, 1, 131-160. 